\title{
Meseres corlissi: a rare oligotrich ciliate adapted to warm water and temporary habitats
}

\author{
Thomas Weisse* \\ Institute for Limnology of the Austrian Academy of Sciences, Mondseestr. 9, 5310 Mondsee, Austria
}

\begin{abstract}
The temperature response of the oligotrich freshwater ciliate Meseres corlissi, a widely distributed but rare species, was investigated in laboratory cultures with the small cryptophyte Cryptomonas sp. as food. Experiments were conducted at saturating food levels and temperatures ranging from 12.5 to $30^{\circ} \mathrm{C}$. The following ecophysiological parameters were measured: ingestion, growth and production rate, cell volume and gross growth efficiency. All these parameters peaked at temperatures ranging from 20 to $30^{\circ} \mathrm{C}$. Encystment was also recorded in the temperature response experiments. Cyst formation was low $\left(<1 \%\right.$ of all ciliates) at temperatures above $20^{\circ} \mathrm{C}$, increased to $18 \%$ at $20^{\circ} \mathrm{C}$ and reached a maximum $(\sim 80 \%)$ at 15 to $17.5^{\circ} \mathrm{C}$. Food limitation had little impact on encystment at $25^{\circ} \mathrm{C}$. Additional experiments at variable food levels yielded the numerical and functional response of the species at the temperature optimum $\left(25^{\circ} \mathrm{C}\right)$. The experimental results suggest that $M$. corlissi is an opportunistic warm water species, able to cope with changes in food and temperature. When adequate environmental conditions are met, this ciliate should be highly competitive in freshwater habitats. The sparse findings of this species from natural habitats suggest, however, that although $M$. corlissi is globally distributed, it is not ubiquitous. The factors that restrict the occurrence of $M$. corlissi in freshwater remain unknown.
\end{abstract}

KEY WORDS: Adaptation · Ciliates $\cdot$ Oligotrichs $\cdot$ Cysts $\cdot$ Temperature response Resale or republication not permitted without written consent of the publisher

\section{INTRODUCTION}

Small and medium-sized oligotrich species dominate the ciliate community in terms of cell numbers and biomass in many freshwater environments (Beaver \& Crisman 1989, Laybourn-Parry 1994, Weisse \& Müller 1998 and references therein). In particular, the planktonic realm is characterised by the high percentage of oligotrichs and may be classified as 'Oligotrichetea' (Foissner et al. 1991). Although there is evidence for an endemic ciliate fauna in some freshwater lakes (reviewed by Foissner 1999, Foissner et al. 1999), it is commonly believed that most free-living ciliates are globally distributed (e.g. Finlay \& Fenchel 1999, Foissner 1999) and 'adapted to very wide ranges of ecologically important factors such as temperature and salinity' (Finlay 2002). Accordingly, the potential for local adaptation to specific environmental factors has been studied only little.
The aim of this study was to test for ecophysiological adaptation of a ciliate to a peculiar aquatic environment, using the oligotrich species Meseres corlissi as a model organism for globally distributed but rare protist species. This species was first described from an infusion of dried mud samples taken from an astatic meadow-pond in Salzburg, Austria, and taxonomically placed into the family Halteriidae (Petz \& Foissner 1992). The cell size of $M$. corlissi is in vivo approximately 70 to $90 \times 60 \mu \mathrm{m}$, and the species is morphologically similar to common species among Halteria and Strombidium (Petz \& Foissner 1992). Formation and structure of the characteristic resting cysts of M. corlissi have been reported elsewhere (W. Foissner, H. Müller, T. Weisse unpubl.). The ecology of the new species remained uninvestigated. An inventory of a new mud sample taken from the original type location in Salzburg in November 2002 confirmed the original finding (H. Müller unpubl.). The species was, however, 
not found in detailed surveys of the ciliate fauna in a eutrophic and an oligomesotrophic lake close to the type location (Foissner et al. 1999, W. Foissner, H. Müller, T. Weisse unpubl.). Further sporadic records of M. corlissi are known from a salt-pan of the Etosha National Park, Namibia (Foissner et al. 2002), and from the Murray River flood plain, Australia (W. Foissner pers. comm.). The material used in the present study was obtained from a fog rain forest in the Dominican Republic. The ciliate was isolated from a raw culture and adapted to the conditions used in our laboratory to rear planktonic oligotrich and prostome ciliates (e.g. Weisse et al. 2001, Weisse \& Lettner 2003). The temperature response of $M$. corlissi was then investigated in cultures with the small cryptophyte Cryptomonas sp. as food. This and similar small cryptophyte species are the preferred food of many planktonic ciliates (summarised by Weisse \& Müller 1998).

\section{MATERIALS AND METHODS}

Origin of the culture and stock culture conditions. The original material of Meseres corlissi Petz and Foissner 1992 was provided by Walter Till (University of Vienna) from a fog rain forest near the town of Santiago, Dominican Republic, where it was collected from a reservoir of a tree bromelia, Guzmania ekmanii. Wilhelm Foissner (University of Salzburg) identified the species and established raw cultures of $M$. corlissi on Eau de Volvic enriched with some squashed wheat grains. This raw culture was purified and adapted to an algal diet composed of Cryptomonas sp. strain 979-4 (Culture Collection of Algae, SAG, Göttingen, Germany) in the laboratory. Length and width of the algae were $\sim 10 \times 6 \mu \mathrm{m}$, the average cell volume ranged from 160 to $220 \mu \mathrm{m}$, depending on temperature and light conditions (pers. obs.). Both the ciliate and cryptophyte were maintained in modified Woods Hole medium (MWC medium, Guillard \& Lorenzen 1972) at $15 \pm 1^{\circ} \mathrm{C}$ and continuous light $\left(100 \mu \mathrm{mol}\right.$ photons $\left.\mathrm{m}^{-2} \mathrm{~s}^{-1}\right)$; the ciliate culture received additionally Eau de Volvic ( $25 \%$ of the total volume, $50 \mathrm{ml}$ ). This monospecific, non-clonal ciliate culture was then used to investigate the growth and feeding response of $M$. corlissi reported in this paper. Although no attempt was made to select an individual clone from the raw culture, it seems plausible that one or a few clones became dominant in the course of the continued culturing in the laboratory. Conjugation, i.e. sexual reproduction, was never observed in the course of this study. The experiments described were performed within half a year after sampling and establishment of the raw culture.

Temperature response experiments. Ciliates were taken from exponentially growing stock cultures. An inoculum was transferred to sterile $200 \mathrm{ml}$ tissueculture bottles containing MWC medium, Cryptomonas sp. and Eau de Volvic. Over 5 to 7 d, ciliates and prey were step-wise acclimated to experimental food levels and temperatures $(12.5,15,17.5,20,22.5,25,27.5$ and $30 \pm 0.5^{\circ} \mathrm{C}$ ). The target temperatures were reached by changing the incubation temperature by up to $3^{\circ} \mathrm{C} \mathrm{d}^{-1}$. Light level for ciliates during the acclimation period was $\sim 70 \mu \mathrm{mol}$ photons $\mathrm{m}^{-2} \mathrm{~s}^{-1}$ in a $12: 12 \mathrm{~h}$ light:dark (L:D) rhythm. Prey levels were monitored with an electronic particle counter (CASY 1-model TTC, Schärfe System; Weisse \& Kirchhoff 1997), and the ciliates were regularly fed to maintain saturating food levels.

After the temperature acclimation period, 20 to $40 \mathrm{ml}$ of the ciliate cultures were inoculated into sterile $200 \mathrm{ml}$ tissue-culture bottles containing 80 to $100 \mathrm{ml}$ of medium and acclimated prey and $40 \mathrm{ml}$ Eau de Volvic, at prey

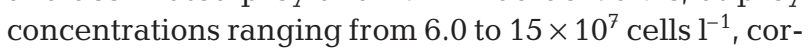
responding to carbon levels of $\sim 1.7$ to $2.8 \mu \mathrm{g} \mathrm{C} \mathrm{ml}^{-1}$. To render this study comparable to previous investigations, prey cell volume was converted to carbon units using $\mathrm{C}$ $(\mathrm{pg})=0.109 \mathrm{~V}\left(\mathrm{\mu m}^{3}\right)^{0.991}$ (Montagnes et al. 1994)

The experiments lasted for $48 \mathrm{~h}$. Light conditions were identical to those of the acclimation period. Samples were taken from containers at $24 \mathrm{~h}$ intervals and fixed with Lugol's iodine (final concentration $2 \%$ vol/vol). Algal abundance in each container was measured by an electronic particle counter and microscopically, together with the ciliates. The latter were counted using a Sedgewick Rafter cell of $1 \mathrm{ml}$ volume or settling chambers of $3 \mathrm{ml}$ volume. Each experiment was run with 3 replicates plus 1 control without ciliates. Results reported are means \pm 1 SD.

Numerical and functional response experiments. The ciliates were carefully adapted to experimental food and temperature conditions over 72 to $96 \mathrm{~h}$, similar to earlier experiments with other planktonic ciliates (Weisse et al. 2001, 2002). The numerical and functional response of Meseres corlissi was measured in 10 experimental treatments at $25^{\circ} \mathrm{C}$ and a $12: 12 \mathrm{~h} \mathrm{~L}: \mathrm{D}$ rhythm over $48 \mathrm{~h}$. Food levels ranged from 0.2 to $15 \times$ $10^{7}$ cells $\mathrm{l}^{-1}$, corresponding to carbon levels ranging from 0.06 to $2.72 \mu \mathrm{g} \mathrm{C} \mathrm{ml}{ }^{-1}$ (see Fig. 3). Three controls without ciliates were run at high, medium and low food levels. Samples were taken at 6 to $12 \mathrm{~h}$ intervals.

Formation of cysts. The occurrence of cysts was monitored in each of the temperature response experiments (24 and $48 \mathrm{~h}$ after the beginning of the experiment) and in the numerical/functional response experiments. A part of the latter, at the lowest food levels, was extended to $72 \mathrm{~h}$ to reveal if extended periods of starvation increase the proportion of cysts among the ciliate population. The fraction of cysts was calculated as the number of cysts in a sample, divided by the total number of active plus encysted ciliates. 
Cell volume. Cell volume of active ciliates and cysts was determined from length and width measurements of Lugol's fixed material, assuming a prolate spheroid shape with circular cross-section. Measurements were made on 50 ciliates obtained at the end of the experiment from each treatment, using an inverted microscope and an image analysis system (LUCIA version 4.51, Laboratory Imaging). Additionally, cell size of live ciliates and prey was measured with an electronic particle counter (CASY 1-model TTC, Schärfe System; Weisse \& Kirchhoff 1997). For ciliates, the remaining volume from each experimental treatment was filtered through $30 \mu \mathrm{m}$ mesh gauze, the retentate resuspended in an isotonic solution (CASYtone, Schärfe System) and measured immediately. This procedure required a minimum of approximately 500 ciliates $\mathrm{ml}^{-1}$ to yield statistically reliable results.

The volume of live trophic cells was, on average, $30 \%$ smaller than the cell volume derived from image analysis measurements of Lugol's fixed material. This difference may not only result from the effect of the fixative but may also reflect the fact that the assumption of a prolate spheroid with circular cross-section overestimates the true cell volume; note that the third dimension (thickness) of the ciliates could not be measured by image analysis. In those cases in which ciliate volume could not be measured with live material (at 12.5 and $17.5^{\circ} \mathrm{C}$ ), values reported in Fig. $1 \mathrm{~B}$ were estimated by image analysis and corrected by a factor of 0.7 .

Calculation of experimental results. Ciliate growth rate $(\mu)$ was determined from changes in cell numbers, assuming exponential growth over the experimental period according to:

$$
\mu=\ln \left(N_{t} / N_{0}\right) / t
$$

where $N_{0}$ and $N_{t}$ are ciliate numbers at the beginning and end of the experimental period, respectively; $\mu\left(\mathrm{d}^{-1}\right)$ is the intrinsic rate of increase and $t$ is the duration of the experiment (d). Results were calculated for each $24 \mathrm{~h}$ interval separately because food concentrations were declining when ciliates reached higher numbers during the second day of the experiment. Ciliate production $\left(\mu \mathrm{m} \mathrm{d}^{-1}\right)$ was calculated as the product of $\mu$ and the corresponding cell volume.

Ciliate growth rates were related to the geometric mean prey concentration $(P)$ during the experimental period (Frost 1972, Heinbokel 1978) according to:

$$
P=\frac{P_{t}-P_{0}}{\ln \left(P_{t} / P_{0}\right)}
$$

where $P_{0}$ and $P_{t}$ are, respectively, the initial and final prey concentrations (cells $\mathrm{l}^{-1}$ ) during incubations.

Ciliate ingestion rate $\left(I\right.$, in Cryptomonas sp. ciliate $^{-1}$ $\mathrm{h}^{-1}$ ) was calculated according to:

$$
I=\frac{(P \times g)}{R_{m}}
$$

where $g$ is the grazing rate $\left(\mathrm{h}^{-1}\right), R_{m}$ is the ciliate abundance $\left(1^{-1}\right)$ in the experimental containers. $g$ was calculated as:

$$
g=\frac{\ln \left(C_{t} / C_{0}\right)-\ln \left(P_{t} / P_{0}\right)}{\Delta t}
$$

where $C_{0}$ and $C_{t}$ are the initial and final Cryptomonas sp. numbers in the controls. $g$ is equivalent to $\mu$ of Cryptomonas sp. observed in the controls minus growth rates measured in the experimental containers. These rates were calculated according to Eq. (1), replacing $N_{t}$ and $N_{0}$ by $C_{0}$ and $C_{t}$ and $P_{t}$ and $P_{0}$, respectively.

The numerical response data of the ciliate (see Fig. 2) were fitted to Eq. (5), which includes a positive $x$-axis intercept, using the Marquardt-Levenberg algorithm (SigmaPlot 2000, version 6.10):

$$
\mu=\frac{\mu_{\max }\left(P-x^{\prime}\right)}{k^{\prime}+\left(P-x^{\prime}\right)}
$$

where $\mu$ is growth rate, $\mu_{\max }$ is the maximum growth rate, $P$ is prey concentration (Eq. 2), $k^{\prime}$ is a constant, and $x^{\prime}$ is the $x$-axis intercept (i.e. threshold concentration, where $\mu=0$ ).

The functional response data (see Fig. 3) were first fit to an equation similar to Eq. (5), but $\mu$ and $\mu_{\max }$ were replaced by the parameters $I$ and $I_{\max }$ denoting actual and maximum ingestion rate (Eq. 3 ); $k^{\prime}$ was replaced by the constant $k$, and $x^{\prime}$ remained the prey concentration, where $I=0$. Since the statistical analysis revealed that $x^{\prime}$ was not significantly different from zero, i.e. that there was no threshold food level at which ingestion ceased, the data reported in Fig. 3B were then fitted to:

$$
I=\frac{I_{\max } P}{k+P}
$$

The proportion of cysts $(y)$ versus food concentration $(P)$ was fitted to Eq. (7), using nonlinear regression analysis in SigmaPlot:

$$
y=a \mathrm{e}^{-c P}
$$

where $a$ and $c$ are constants.

To express rates and ratios in Eqs. (2) to (7) in carbon units, cell numbers of Cryptomonas sp. were multiplied by the average algal cell volume measured in each experiment and converted to carbon assuming $\mathrm{C}(\mathrm{pg})=0.109 \mathrm{~V}\left(\mu \mathrm{m}^{3}\right)^{0.991}$ (Montagnes et al. 1994).

Statistical analyses. One-way analysis of variance (ANOVA) and Tukey's test were used to test if the overall impact of temperature on the measured parameters was significant $(p<0.05)$ and to reveal significant differences between results obtained at different temperatures. All statistical analyses were performed using SigmaStat (Version 2.03). 


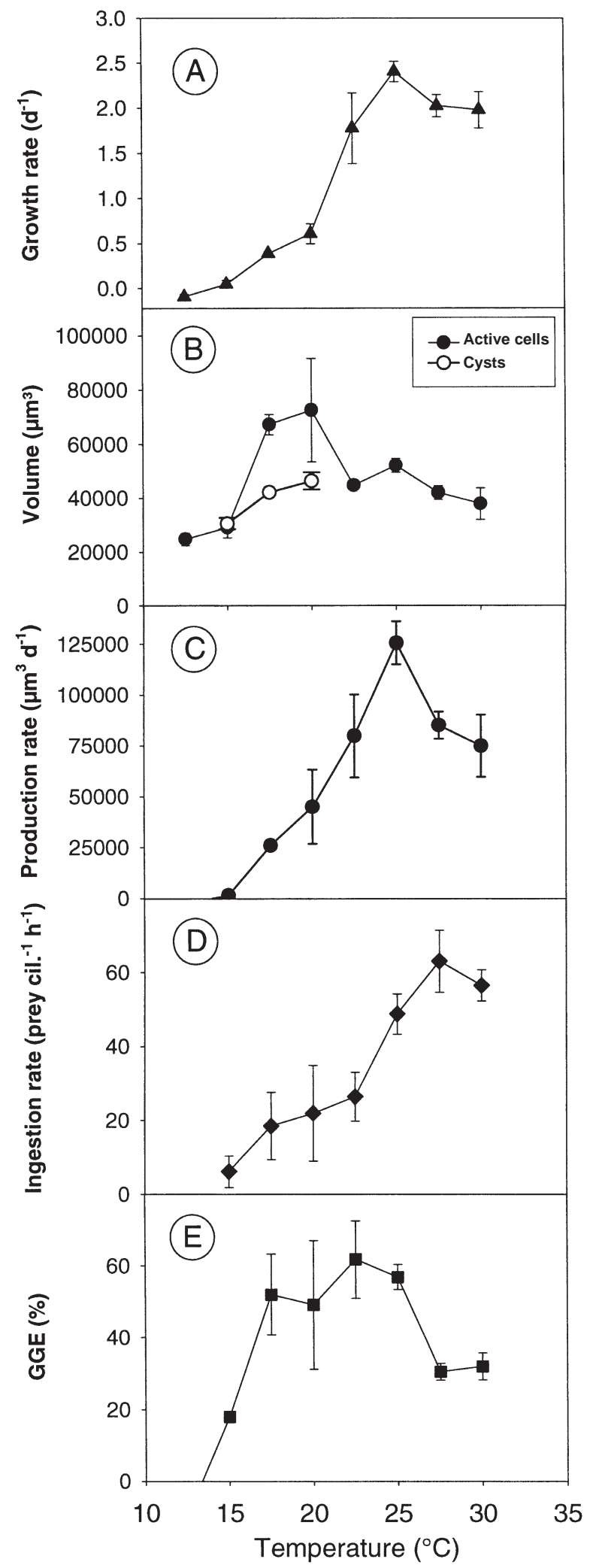

Fig. 1. Meseres corlissi. (A) Growth rate, (B) cell volume, (C) cellular production rate, (D) ingestion rate and (E) gross growth efficiency (GGE) of the ciliate (cil.) versus experimental temperature. Error bars denote $\pm 1 \mathrm{SD}$

\section{RESULTS}

\section{Growth, grazing and production rates of Meseres corlissi versus temperature}

All ecophysiological parameters investigated were significantly impacted by temperature (1-way ANOVA, p < 0.05). Positive population growth of Meseres corlissi was recorded over a temperature range from 15 to $30^{\circ} \mathrm{C}$. Growth rate peaked at $25^{\circ} \mathrm{C}\left(2.4 \mathrm{~d}^{-1}\right)$ and was not significantly different (1-way ANOVA, Tukey test) at the highest experimental temperatures (Fig. 1A). Temperatures $>30^{\circ} \mathrm{C}$ were not tested because the Cryptomonas species used as food does not tolerate such high temperatures over several days (pers. obs.). The growth rate of $M$. corlissi declined to $0.05 \mathrm{~d}^{-1}$ at $15^{\circ} \mathrm{C}$ and was negative $\left(-0.10 \mathrm{~d}^{-1}\right)$ at $12.5^{\circ} \mathrm{C}$.

Mean cell volume of the active Meseres corlissi cells increased significantly from 12.5 to $17.5^{\circ} \mathrm{C}$ (Fig. 1B) and then declined linearly at a rate of $0.04{ }^{\circ} \mathrm{C}^{-1}$ from 20 to $30^{\circ} \mathrm{C}$, relative to the maximum volume measured at $20^{\circ} \mathrm{C}$ (least-squares linear regression, $\mathrm{r}^{2}=0.693$ ). In spite of this significant trend, cell volume was not significantly different between $22.5,27.5$ and $30^{\circ} \mathrm{C}$ (1-way ANOVA, Tukey test). Cell volume of the cysts measured at the temperatures at which cyst formation occurred in higher numbers (reported below) was similar to or lower than that of the active cells (Fig. 1B). Production rate increased linearly from 12.5 to $25^{\circ} \mathrm{C}$ and declined at higher temperatures (Fig. 1C). The peak production rate was significantly higher than rates measured at all other temperatures, while production rates calculated at $22.5,27.5$ and $30^{\circ} \mathrm{C}$ were not significantly different.

At $25^{\circ} \mathrm{C}$, relatively small cells were able to achieve not only higher growth rates (Fig. 1A), but also higher production (Fig. 1C) and ingestion rates (Fig. 1D) than larger cells at lower temperatures. Ingestion rate increased with temperature and was significantly higher at 25 to $30^{\circ} \mathrm{C}$ than at the lower temperatures (Fig. 1D).

Gross growth efficiency (GGE), which denotes the ratio of conversion of food uptake into body biomass of the ciliates (production divided by ingestion), was significantly higher between 17.5 and $25^{\circ} \mathrm{C}$ than at the lower and upper end of the temperature range investigated (Fig. 1E).

\section{Numerical and functional response of Meseres corlissi at $25^{\circ} \mathrm{C}$}

The relationship between growth rate of Meseres corlissi and food concentration (numerical response) was investigated at $25^{\circ} \mathrm{C}$, i.e. the temperature optimum at which growth and production rate and growth 


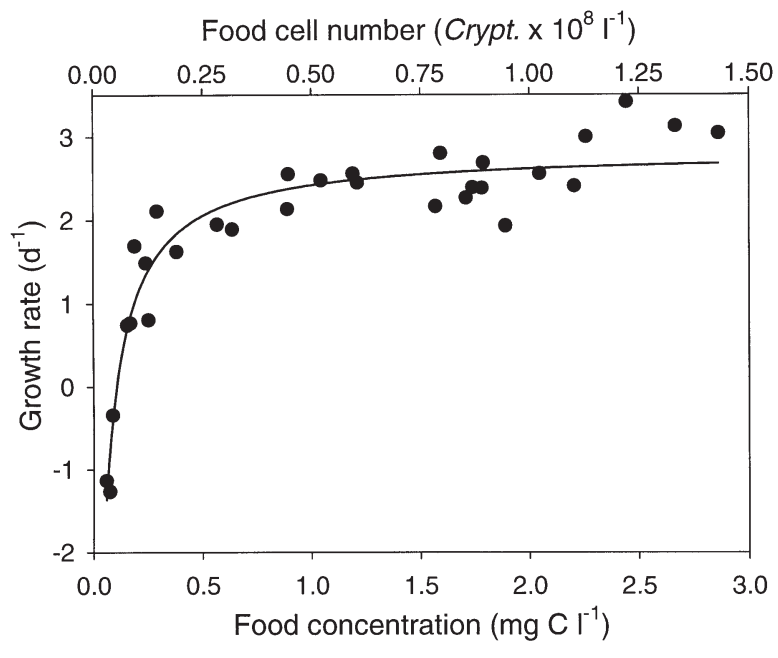

Fig. 2. Meseres corlissi. Relationship between population growth rate and food concentration (numerical response) at $25^{\circ} \mathrm{C}$. Solid curve represents the fit of Eq. (5) to the data (see 'Materials and methods'). See Table 1 for the parameters and error estimates of the curve. Crypt.: Cryptomonas

efficiency peaked for the ciliate (cf. Fig. 1). Growth rate followed a rectangular hyperbolic response to food concentration; it increased rapidly with food concentration at food levels up to $0.25 \mathrm{mg} \mathrm{Cl}^{-1}$, corresponding to $1.3 \times 10^{7}$ Cryptomonas sp. cells $1^{-1}$, and then levelled off (Fig. 2). The threshold level $x^{\prime}$, i.e. the minimum food concentration which must be exceeded to support positive population growth, was $0.10 \pm 0.01 \mathrm{mg} \mathrm{C} \mathrm{l}^{-1}$ (Table 1). The maximum growth rate predicted from the nonlinear regression was $2.82 \mathrm{~d}^{-1}$. The parameters and their error estimates of the curve fit (see 'Materials and methods', Eq. 5) are presented in Table 1.

Similar to growth rate, the functional response, that is consumption rate versus food concentration, followed a rectangular hyperbolic response to food concentration (Fig. 3). In terms of cell numbers, the maximum feeding rate predicted from the nonlinear regression was $56.4 \pm 4.5$ Cryptomonas sp. ciliate ${ }^{-1} \mathrm{~h}^{-1}$ (Fig. 3A), equivalent to $1353 \pm 108$ Cryptomonas sp. ciliate $^{-1} \mathrm{~d}^{-1}$. The corresponding ingestion rate expressed in carbon units and the parameter estimates of the curve fit are presented in Fig. 3B and Table 1. In contrast to the numerical response, there was no

Table 1. Parameter values for the numerical and functional response curves presented in Figs 2 \& 3. See 'Materials and methods' (Eq. 5) for further explanation. Experiments were conducted at $25^{\circ} \mathrm{C}$

\begin{tabular}{|lcccc|}
\hline Curve & $\begin{array}{c}\mu_{\max } \\
\left(\mathrm{d}^{-1}\right)\end{array}$ & $\begin{array}{c}I_{\max } \\
\left(\mathrm{ng} \mathrm{C} \mathrm{ciliate}^{-1} \mathrm{~d}^{-1}\right)\end{array}$ & $\begin{array}{c}k \text { or } k^{\prime} \\
\left(\mathrm{mg} \mathrm{C} \mathrm{l}^{-1}\right)\end{array}$ & $\begin{array}{c}x^{\prime} \\
\left(\mathrm{mg} \mathrm{C} \mathrm{l}^{-1}\right)\end{array}$ \\
\hline $\begin{array}{l}\text { Numerical response } \\
\text { Functional response }\end{array}$ & $\begin{array}{c}2.82 \pm 0.11 \\
-\end{array}$ & - & $\begin{array}{c}0.13 \pm 0.02 \\
0.3 \pm 2.0\end{array}$ & $\begin{array}{c}0.33 \pm 0.17 \\
-0.01\end{array}$ \\
\hline
\end{tabular}

Food cell number (Crypt. $\times 10^{8} \mathrm{I}^{-1}$ )

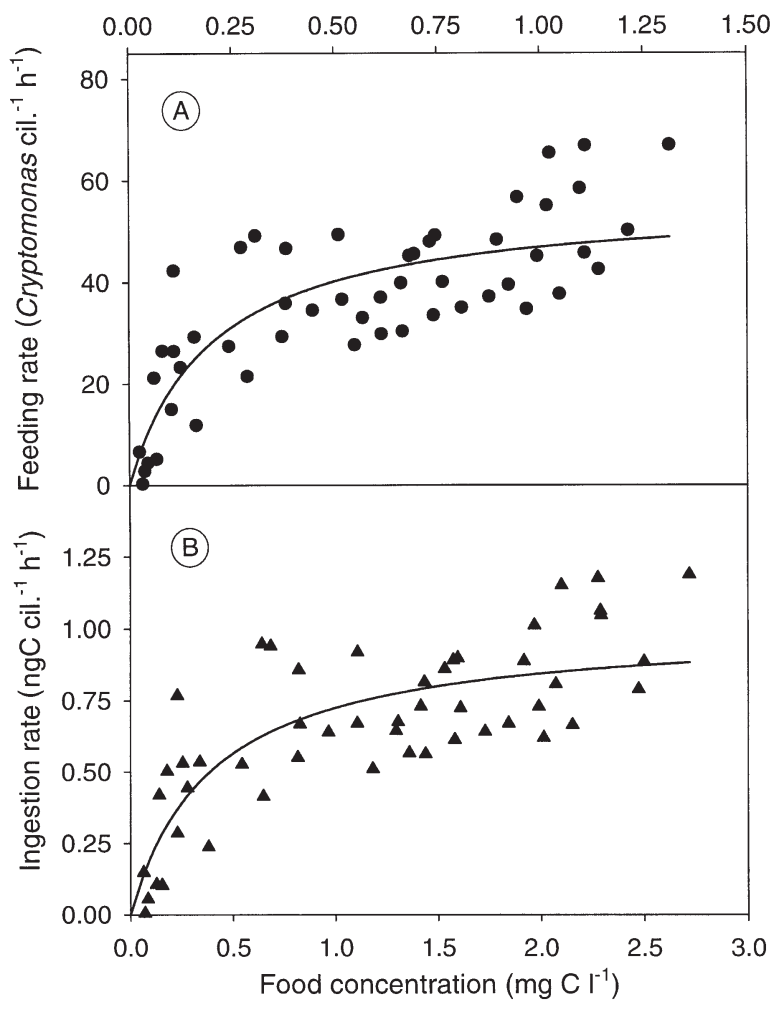

Fig. 3. Meseres corlissi. Relationship between food uptake, as (A) number of prey and (B) ng C, and food concentration (functional response) at $25^{\circ} \mathrm{C}$. Solid curve represents the fit of Eq. (6) to the data (see 'Materials and methods'). See Table 1 for the parameters and error estimates of the curve. Crypt.: Cryptomonas; cil.: ciliate

threshold concentration of the functional response curve significantly different from zero. In other words, there was no indication that Meseres corlissi stopped feeding at (very) low food levels.

\section{Cyst formation of Meseres corlissi}

In the temperature response experiments conducted at saturating food levels (Fig. 1), the ciliates had formed cysts at temperatures $\leq 20^{\circ} \mathrm{C}$ in all subsamples taken $24 \mathrm{~h}$ after the beginning of the experiment. The fraction of encysted cells increased dramatically at temperatures $<20^{\circ} \mathrm{C}$ (Fig. 4). At temperatures $>20^{\circ} \mathrm{C}$, cysts occurred only sporadically; the proportion of cysts could not be quantified at $12.5^{\circ} \mathrm{C}$ because at this temperature the ciliate cell numbers were too low $24 \mathrm{~h}$ after the beginning of the experiment to quantify active cells and cysts with reliable statistics. 


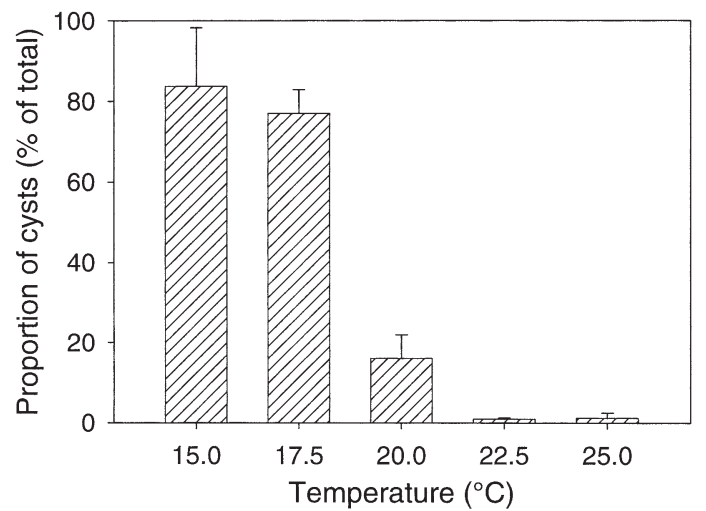

Fig. 4. Meseres corlissi. Proportion of encysted cells (percentage of total ciliates) versus temperature at saturating food concentrations. Error bars denote $+1 \mathrm{SD}$

To investigate if food limitation and prolonged starvation may trigger cyst formation at higher temperatures, the occurrence of cysts was monitored in most treatments of the functional response experiment (cf. Fig. 3B), and a part of this experiment (at low food levels) was continued for $72 \mathrm{~h}$. The functional response experiments confirmed the result from the temperature response experiments at $25^{\circ} \mathrm{C}$ : only 40 cysts were counted among $>3000$ ciliates, i.e. only $1.3 \%$ of all ciliates had formed cysts in these experiments within the first $48 \mathrm{~h}$, and there was no obvious relation to food (Fig. 5). Prolonged exposure to low food concentrations $\left(<0.1 \mathrm{mg} \mathrm{C}^{-1}\right)$ increased the proportion of cysts to a maximum of $10.3 \%$ of all ciliates counted in a given treatment. With these results included, a nonlinear regression according to Eq. (7) (see 'Materials and methods') yielded a significant association between the relative amount of cysts and food (ANOVA, $F=$ $7.015, p=0.0147$ ). The predictive power of the regres-

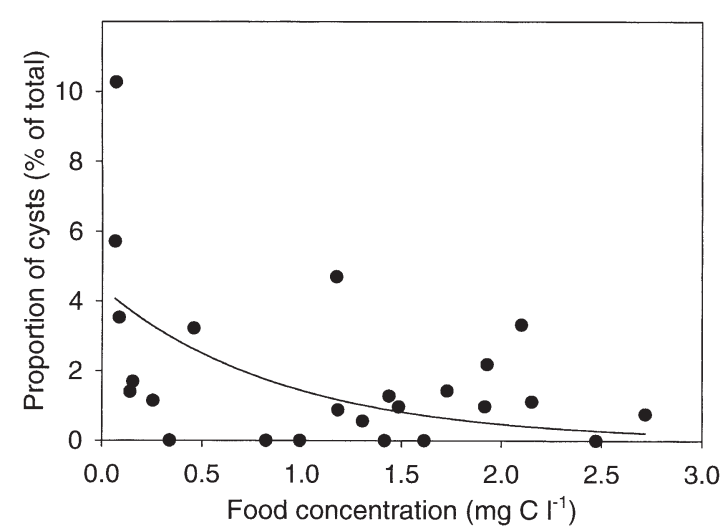

Fig. 5. Meseres corlissi. Proportion of encysted cells (percentage of total ciliates) versus food concentration at $25^{\circ} \mathrm{C}$. Samples were taken 24,48 and $72 \mathrm{~h}$ after the beginning of the experiment. Solid curve represents the fit of Eq. (7) to the data (see 'Materials and methods') sion model was, however, low (adjusted $\mathrm{R}^{2}=0.207$ ), suggesting that the overall impact of food on the formation of cysts was low.

\section{DISCUSSION}

\section{Temperature reaction norm of Meseres corlissi}

Temperature significantly impacted all ecophysiological parameters of Meseres corlissi investigated (Fig. 1), and all parameters peaked at temperatures ranging from 20 to $30^{\circ} \mathrm{C}$. At temperatures $<20^{\circ} \mathrm{C}$, the vast majority of the ciliates responded by forming cysts within $24 \mathrm{~h}$ (Fig. 4). The formation of cysts was obviously triggered by low temperature, because mass encystment could not be induced by food limitation at $25^{\circ} \mathrm{C}$ (Fig. 5). Note that it was not possible to prolong the period of starvation over more than $72 \mathrm{~h}$, because the ciliates died off if food concentration fell below $0.1 \mathrm{mg} \mathrm{Cl}^{-1}$ (Fig. 2, Table 1).

Not only ingestion and growth rates but also cell volume and GGE were low at 12.5 and $15^{\circ} \mathrm{C}$ (Fig. 1). Accordingly, production rate of the ciliates measured at $15^{\circ} \mathrm{C}$ amounted to only $1.2 \%$ of the peak production rate measured at $25^{\circ} \mathrm{C}$ (Fig. $1 \mathrm{C}$ ). The latter may indicate the temperature optimum of the species.

If the entire temperature range tested is considered, cell volume (Fig. 1B) did not decline linearly with temperature as suggested for marine diatoms (Montagnes \& Franklin 2001). Cell volume peaking at intermediate temperatures has been previously observed in planktonic ciliates (Weisse et al. 2002, Weisse \& Lettner 2003). Recently, Atkinson et al. (2003) concluded from a comprehensive statistical analysis of literature data that at extremely low temperatures, at which population growth is prevented, the size of aquatic protists increases with temperature. At higher temperatures, at which population growth is positive, cell volume declines linearly. In a study by Atkinson et al. (2003), the overall relative thermal sensitivity of cell volume was $-0.025{ }^{\circ} \mathrm{C}^{-1}$ of the cell volume at the reference temperature of $15^{\circ} \mathrm{C}$; the mean relative thermal sensitivity of cell volume increased to $-4 \%{ }^{\circ} \mathrm{C}^{-1}$ if only those datasets that gave significant linear negative regressions were considered. An identical relative thermal sensitivity of cell volume, $-0.04{ }^{\circ} \mathrm{C}^{-1}$, was obtained for Meseres corlissi in the present study from 20 to $30^{\circ} \mathrm{C}$. Some caution is needed with this conclusion, because the statistical analysis (1-way ANOVA) revealed that the volume was not different at 3 out of the 5 temperatures measured over this temperature range.

High growth and ingestion rates measured at the upper end of the temperatures tested (Fig. 1A and D) may be misleading with respect to the overall temper- 
ature response of the species, i.e. the temperature reaction norm. These high rates were measured at saturating food conditions $\left(>1 \mathrm{mg} \mathrm{C}^{-1}\right.$ ), which are met in eutrophic environments only. The environmental conditions and the food levels, in particular, in the tank of the bromeliads from which the ciliate was isolated remain unknown. The threshold food concentration needed to sustain zero population growth may steeply increase at the far end of the temperature tolerance of planktonic ciliates (Weisse et al. 2002). The highest ingestion rates measured at the warmest temperatures did not yield a maximum production rate, because the conversion of the energy uptake was reduced when temperature exceeded $25^{\circ} \mathrm{C}$ (Fig. 1E).

Similar to cell volume, GGE was not inversely related to temperature over the entire temperature range, as inferred for ciliates in general from a statistical analysis of literature data from 74 observations (Straile 1997). I conclude that the low cell volume and reduced GGE measured at the low temperatures reflect temperature stress at the low end of the temperature tolerance of the ciliate. Similarly, physiological stress was obvious at the high end of the temperature range investigated. A reduction in production and GGE at 27.5 and $30^{\circ} \mathrm{C}$, while ingestion was still high, indicates that metabolic maintenance costs (respiration) were increasing at the high temperatures. Net growth efficiency, which denotes the proportion of the assimilated energy that can be used for production, is declining and relatively more energy is lost as heat because respiration increases disproportionately at temperatures above the temperature optimum. In other words, beyond the temperature optimum more of the assimilated energy is directed to maintenance, leaving little to be partitioned into growth and reproduction. The GGE curve may thus serve as another indicator for the temperature reaction norm of the species.

\section{Meseres corlissi: a globally distributed but locally thriving ciliate adapted to astatic warm water environments}

Including the temperature response of cyst formation, all results presented in this study suggest that the isolate of Meseres corlissi from the Dominican Republic is adapted to unsteady warm water environments. The air temperature in the Dominican Republic usually ranges from 23 to $28^{\circ} \mathrm{C}$. High maximum ingestion, growth and production rates, combined with the ability to form cysts, should enhance the chance of its widespread dispersal. The origin of the isolate and the few other observations of this species are in agreement with this conclusion. Since several attempts in our laboratory failed to adapt the ciliate gradually to tempera- tures $<15^{\circ} \mathrm{C}$, I conclude that the temperature reaction norm of this culture is genetically fixed. It is at present, however, an open question whether the results reported in this study are representative of the isolate from the Dominican Republic only or if they adequately characterise the reaction norm of the species.

Findings of Meseres corlissi active cells or cysts are known from 4 continents and diverse habitats such as the reservoir of a tree bromelia (Foissner et al. 2003), an astatic, temperate freshwater pond (Petz \& Foissner 1992) and a subtropical salt-pan with irregular floods (Foissner et al. 2002). A common aspect of all these findings is that the distribution of $M$. corlissi was locally and/or temporarily highly restricted. In Namibia, for instance, the species was found only at 1 out of 73 sites investigated (Foissner et al. 2002). Similarly, the occurrence of $M$. corlissi in tank bromeliads is highly sporadic (Foissner et al. 2003, W. Foissner pers. comm.). Apparently, M. corlissi is globally distributed but it is not ubiquitous. This is remarkable considering that, due to the variety of the known habitats, the species should be able to adapt to a wide range of environmental conditions. This conclusion is further supported by the experimental results obtained in the present study. The isolate was easily adjusted (1) to a bacterial and/or flagellate diet (by W. Foissner, in the raw culture) and then (2) to a small cryptophyte known as optimum food for many planktonic ciliates and rotifers (Müller \& Geller 1993, Weisse \& Müller 1998, Weisse \& Frahm 2001, Weisse \& Lettner 2003). The versatility of the ciliate observed in the present study is noteworthy considering that $M$. corlissi may not be a typical euplanktonic species, although in cultures it swims permanently at a speed comparable to that of similar sized oligotrichs (pers. obs.).

Growth, ingestion and production rates and GGE of Meseres corlissi were similar or higher than those of closely related planktonic ciliates under similar experimental conditions (Müller \& Geller 1993, Weisse \& Montagnes 1998, Weisse et al. 2001, Weisse \& Lettner 2003). The numerical and functional response curves further demonstrate that $M$. corlissi should be highly competitive in many warm-temperate and (sub)tropical lakes. The threshold food concentration for population growth is comparable to that of other planktonic ciliate species obtained under similar food and temperature conditions (Müller \& Schlegel 1999, Weisse et al. 2002), but at the high end of values reported for oligotrich ciliates (Jakobsen \& Hansen 1997 and references therein, Montagnes \& Lessard 1999, Müller \& Schlegel 1999). The threshold level corresponds to a chlorophyll a concentration of approximately $2.5 \mu \mathrm{g} \mathrm{l^{-1 }}$, assuming a carbon to chlorophyll a ratio of 40:1 (Banse 1977, Montagnes et al. 1994), or to a bacterial abundance of 2 to $10 \times 10^{9}$ cells $1^{-1}$, assuming a bacterial carbon content 
of 10 to $50 \mathrm{fg} \mathrm{cell}^{-1}$ (Fukuda et al. 1998 and references therein). Therefore, although $M$. corlissi does not need particularly high food concentrations, food limitation may be one of the factors restricting the occurrence of this ciliate in aquatic habitats to short periods.

Meseres corlissi is able to form cysts within a few hours (W. Foissner, H. Müller, T. Weisse unpubl.). The resting cysts are covered by a coat of small spheres (lepidosomes), embedded in a mucopolysaccharide-rich, fibrillar mucilage. The cyst wall, the mucilage, and the lepidosomes are highly resistant to inorganic and organic solvents (W. Foissner, H. Müller, T. Weisse unpubl.). In completely dry mud, cysts of M. corlissi survived for several months ( $\mathrm{H}$. Müller unpubl.). Although the results from this study suggest that cyst formation in M. corlissi is primarily triggered by temperature, encystment will enable the species to survive unfavourable environmental conditions such as food shortage or dry periods in astatic water bodies. If M. corlissi is globally dispersed, is able to survive adverse conditions and is such a highly competitive species relative to closely related, similarly sized other ciliates, why then is it not found everywhere where food is abundant?

The species is too large and conspicuous to be overlooked in natural samples easily. It seems possible that Meseres corlissi was confused in previous ecological investigations with similar species such as Halteria bifurcata (Foissner et al. 1999). M. corlissi was, however, not found in detailed inventories of temperate ponds and lakes by experienced ecologists and taxonomists (Foissner et al. 1999, Finlay \& Maberly 2000, W. Foissner pers. comm.). Similarly, it was not found among numerous cryptic freshwater species in a hypersaline lagoon (Esteban \& Finlay 2003). I therefore infer that, in spite of its global dispersal, $M$. corlissi is a rare species, relative to other common planktonic oligotrichs of the genera Halteria and Strobilidium/ Rimostrombidium (Foissner et al. 1999). This does not rule out that $M$. corlissi will be recorded from other habitats in the future, since vast areas such as South America remain at present virtually unexplored for free-living ciliates (Foissner 2003).

In summary, the occurrence of Meseres corlissi in freshwater appears to be restricted to particular habitats and periods, due to the as yet unknown specific ecophysiological demands of this species and/or intrinsic factors such as an unusually short life span of the trophic cells. In spite of its high potential competitiveness with respect to ecologically important factors such as food and temperature, this species does not adapt to wide ranges of environmental conditions. Clearly, more observations with $M$. corlissi isolates obtained from geographically distant and ecologically different locations are needed to elucidate the ecophysiology of this species in more detail.
Acknowledgements. I am grateful to Professors W. Till and W. Foissner for providing the raw Meseres corlissi material, and further to W. Foissner for identifying the species and numerous helpful hints in the course of this investigation. I thank D. Montagnes, H. Müller, W. Foissner and 3 anonymous reviewers for their comments on earlier versions of this manuscript. This study benefited from the skilful technical assistance of P. Stadler. Financial support was provided by the Austrian Science Foundation, FWF project P16796-B06.

\section{LITERATURE CITED}

Atkinson, D, Ciotti, BJ, Montagnes, DJS (2003) Protists decrease in size linearly with temperature: ca. $2.5 \%{ }^{\circ} \mathrm{C}^{-1}$. Proc R Soc Lond B 270:2605-2611

Banse K (1977) Determining the carbon to chlorophyll ratio of natural phytoplankton. Mar Biol 41:199-212

Beaver JR, Crisman TL (1989) The role of ciliated protozoa in pelagic freshwater ecosystems. Microb Ecol 17:111-136

Esteban GF, Finlay BJ (2003) Cryptic freshwater ciliates in a hypersaline lagoon. Protist 154:411-418

Finlay BJ (2002) Global dispersal of free-living microbial eukaryote species. Science 296:1061-1063

Finlay BJ, Fenchel T (1999) Divergent perspectives on protist species richness. Protist 150:229-233

Finlay BJ, Maberly SC (2000) Microbial diversity in Priest Pot-a productive pond in the English Lake District. Freshwater Biological Association, Ambleside

Foissner W (1999) Protist diversity: estimates of the nearimponderable. Protist 150:363-368

Foissner W (2003) Morphology and ontogenesis of Bromeliophrya brasiliensis gen. n., sp. n., a new ciliate (Protozoa: Ciliophora) from Brazilian tank bromeliads (Bromeliaceae). Acta Protozool 42:55-70

Foissner W, Blatterer H, Berger H, Kohmann F (1991) Taxonomische und ökologische Revision der Ciliaten des Saprobiensystems. Band I: Cyrtophorida, Oligotrichida, Hypotrichia, Colpodea. Informationsberichte des Bayer, Vol 1/91. Landesamt für Wasserwirtschaft, München, p 1-478

Foissner W, Berger H, Schaumburg J (1999) Identification and ecology of limnetic plankton ciliates. Informationsberichte des Bayer, Vol 3/99. Landesamt für Wasserwirtschaft, München, p 1-793

Foissner W, Agatha S, Berger H (2002) Soil ciliates (Protozoa, Ciliophora) from Namibia (Southwest Africa), with emphasis on two contrasting environments, the Etosha region and the Namib desert. Denisia 5:1-1459

Foissner W, Strüder-Kypke M, van der Staay GWM, Moonvan der Staay SY, Hackstein JHP (2003) Endemic ciliates (Protozoa, Ciliophora) from tank bromeliads (Bromeliaceae): a combined morphological, molecular, and ecological study. Eur J Protistol 39:365-372

Frost BW (1972) Effects of size and concentration of food particles on the feeding behavior of the marine planktonic copepod Calanus pacificus. Limnol Oceanogr 17:805-815

Fukuda R, Ogawa H, Nagata T, Koike I (1998) Direct determination of carbon and nitrogen contents of natural bacterial assemblages in marine environments. Appl Environ Microbiol 64:3352-3358

Guillard RRL, Lorenzen CJ (1972) Yellow-green algae with chlorophyllide c. J Phycol 8:10-14

Heinbokel JF (1978) Studies on the functional role of tintinnids in the southern California Bight. I. Grazing and growth rates in laboratory cultures. Mar Biol 47:177-189 Jakobsen HH, Hansen PJ (1997) Prey size selection, grazing 
and growth response of the small heterotrophic dinoflagellate Gymnodinium sp. and the ciliate Balanion comatum-a comparative study. Mar Ecol Prog Ser 158: $75-86$

Laybourn-Parry J (1994) Seasonal successions of protozooplankton in freshwater ecosystems of different latitudes. Mar Microb Food Webs 8:145-162

Montagnes DJS, Franklin DJ (2001) Effect of temperature on diatom volume, growth rate, and carbon and nitrogen content: reconsidering some paradigms. Limnol Oceanogr 46: $2008-2018$

Montagnes DJS, Lessard EJ (1999) Population dynamics of the marine planktonic ciliate Strombidinopsis multiauris: its potential to control phytoplankton blooms. Aquat Microb Ecol 20:167-181

Montagnes DJS, Berges JA, Harrison PJ, Taylor FJR (1994) Estimating carbon, nitrogen, protein, and chlorophyll a from volume in marine phytoplankton. Limnol Oceanogr 39:1044-1060

Müller H, Geller W (1993) Maximum growth rates of aquatic ciliated protozoa: the dependence on body size and temperature reconsidered. Arch Hydrobiol 126:315-327

Müller H, Schlegel A (1999) Responses of three freshwater planktonic ciliates with different feeding modes to cryptophyte and diatom prey. Aquat Microb Ecol 17:49-60

Petz W, Foissner W (1992) Morphology and morphogenesis of Strobilidium caudatum (Fromentel), Meseres corlissi n. sp., Halteria grandinella (Müller), and Strombidium rehwaldi $\mathrm{n}$ sp., and a proposed phylogenetic system for oligotrich ciliates (Protozoa, Ciliophora). J Protozool 39:

Editorial responsibility: Karel Šimek,

České Budějovice, Czech Republic
$159-176$

Straile D (1997) Gross growth efficiencies of protozoan and metazoan zooplankton and their dependence on food concentration, predator-prey weight ratio, and taxonomic group. Limnol Oceanogr 42:1375-1385

Weisse T, Frahm A (2001) Species-specific interactions between small planktonic ciliates (Urotricha spp.) and rotifers (Keratella spp.). J Plankton Res 23:1329-1338

Weisse T, Kirchhoff B (1997) Feeding of the heterotrophic freshwater dinoflagellate Peridiniopsis berolinense on cryptophytes: analysis by flow cytometry and electronic particle counting. Aquat Microb Ecol 12:153-164

Weisse T, Lettner S (2003) The ecological significance of intraspecific variation among freshwater ciliates. Verh Int Ver Limnol 28:1880-1884

Weisse T, Montagnes DJS (1998) Effect of temperature on inter- and intraspecific isolates of Urotricha (Prostomatida, Ciliophora). Aquat Microb Ecol 15:285-291

Weisse T, Müller H (1998) Planktonic protozoa and the microbial food web in Lake Constance. Arch Hydrobiol Spec Iss Adv Limnol 53:223-254

Weisse T, Karstens N, Meyer VCM, Janke L, Lettner S, Teichgräber K (2001) Niche separation in common prostome freshwater ciliates: the effect of food and temperature. Aquat Microb Ecol 26:167-179

Weisse T, Stadler P, Lindström ES, Kimmance SA, Montagnes DJS (2002) Interactive effect of temperature and food concentration on growth rate: a test case using the small freshwater ciliate Urotricha farcta. Limnol Oceanogr 47: $1447-1455$

Submitted: April 6, 2004; Accepted: June 25, 2004

Proofs received from author(s): September 16, 2004 